\title{
Buying behaviors in food retail - Offline versus online
}

\author{
Marius BĂLĂȘESCU \\ Transilvania University of Brasov, Brasov, Romania \\ mariusbalasescu@unitbv.ro \\ Simona BĂLĂŞESCU \\ Transilvania University of Brasov, Brasov, Romania \\ simonabalasescu@unitbv.ro
}

\begin{abstract}
The age in which we live is increasingly characterized by the ability of people to communicate without restrictions, to send information without restrictions and to have access to complex information, which can be accessed very quickly. The information economy will penetrate and change almost every aspect of our lives. Thus, there are many examples of companies that no longer need to occupy physical space to carry out their activity. They can be virtual and can work anywhere in the world. In this context we also refer to the transition from classic commerce to online commerce.

In this paper we analyze the behavior of Romanian consumers regarding the purchase of online or offline sales spaces and complete this analysis with a quantitative marketing research on "Opinions and attitudes of Romanians on the purchase of food products from online sales outlets and offline."
\end{abstract}

Keywords: retail, online, information economy, online marketing, online commerce, offline commerce.

\section{Introduction}

E-commerce is an opportunity both to reach new markets and to increase profitability. It also allows the introduction of new management processes that streamline the supply chain and improve the company's efficiency.

The introduction of e-commerce can change the demand model faced by a traditional seller, taking into account both the evolution of overall sales turnover and the characteristics of customer order flows.

From the point of view of the trading system of goods and services, the process is simplified more and more because the number of online stores is constantly growing and has a great impact on consumers, but also on the national economy. However, there are also consumers who prefer the traditional offline store marketing system. Online and offline consumers are largely similar, and it is therefore important for all marketers to consider the Internet an extension of an existing business. In the case of new companies entering the market, it is important to understand both forms of trade, because the physical world will influence behavior in the digital world regardless of where a business operates (Chaffey and Ellis-Chadwick, 2016).

In Romania, the traditional trade represented by small enterprises is predominant, and these companies are mostly placed on marketing channels with lower economic returns. The commercial success of a store depends on the location, the choice of the range of goods and services offered for sale, the ambiance and interior design, but also the exterior. Currently, Romanian retail is characterized by a major and accelerated development, which determines an increase in competitiveness, consolidation of modern forms of retail and last but not least, obtaining more attractive rates of profit.

The dynamic evolution of information and communication technologies has led to profound changes in the field of trade as well. It evolves more and more, from year to year, but at 
the same time it is modeled after the consumer's behavior trying to satisfy the needs of all potential customers. The main advantage of online commerce is the availability of the site, which can be accessed at any time of the day, another advantage is the convenience of shopping, from the comfort of your home.

For offline commerce there are other advantages, such as the ability to view the product before buying, also for many people trade is a way to spend free time.

This paper aims to establish the most important and significant aspects of the analyzed topic, namely the understanding of the behavior of the Romanian consumer when shopping, and the identification of the main differences between online and offline commerce.

\section{Literature review}

Today's consumers have less and less free time. The significant advantage of selling online is that it is available almost non-stop.

Businesses large and small are developing websites and selling through the internet using innovative technology that has more attractive features than traditional marketing. The way information is provided to the consumer can affect the decision to buy a product online. Given this fact, companies can pay special attention to the design and structure of a website. Moreover, online sites with a sales function can be used to present more products than can be presented in a printed catalog. In addition, consumers can benefit from "self-service" services, such as, record keeping, tracking orders, saving personal information for use in future transactions (Dobre \& Milovan, 2019).

The main selection criteria for new stores are some specific parameters of online, such as the maturity of e-commerce, the constraints of adaptability of services, the technological platform in the new market and the level of competition (Wenthru, 2016). However, the basic principles in traditional trade have in mind aspects such as: attractive and commercial presentation; quality staff and services; attractive promotions; self-service system; balanced assortment; adequate equipment as well as layout adapted to customers.

In the online marketplace, consumer purchasing decisions are often influenced by many sources of information, such as search results, customer reviews, social media conversations, and corporate websites. In addition, potential customers use multiple devices, sometimes even simultaneously, to accumulate information that will determine their purchasing decisions. The digital influences of these stores are complemented by exposure to traditional communications, such as TV or radio advertising. The online market is complex and dynamic, and if organizations want to penetrate this market they must carefully analyze the market context they want to be part of, identify their opportunities and then plan how they will compete effectively (Chaffey and Ellis-Chadwick, 2016).

The progress of the Internet and e-commerce is remarkable and has led to changes in markets in many economic sectors. As the online environment is constantly evolving, it has a strong influence on companies' business models, which are moving further and further away from the traditional concept of physical stores, but also from the behavior of consumers who are now more inclined to shop online. Digital marketing represents an innovative concept, which aims at coordinating all online marketing activities by using specific tools and strategies (Neacşu \& Armăsar, 2018).

Online commerce or e-commerce is a buying or selling activity through the transmission of data at a distance, an activity specific to the expansive marketing policy of commercial 
companies. It allows the participation of both natural and legal persons and their state or institutions (Colţea \& collaborators, 2013).

The online environment offers companies various opportunities such as generating brand awareness, shaping the brand image and attitude towards it. Creates loyalty, achieves consumer economic education, marketing research and public relations (Boitor \& collaborators, 2011). Online stores offer its customers the opportunity to express their opinion very simply about his experience with that store, leaving reviews directly on his platform. However, on social media,

PICBE |

613 users post millions of messages expressing their opinions about online retail brands every day, and this helps the way online retail brands communicate and how it works.

Exploring brand content has become essential for businesses to better understand their customers and help generate more advanced exposure for them to gain new market information. (Noor \& Wang, 2019).

The rapid growth of online transactions in the commerce industry raises questions among researchers about the level of satisfaction and loyalty of online store services in relation to the level of satisfaction and loyalty of offline store services.

Compared to the offline environment, the online environment offers more opportunities for interactivity and personalization of product marketing. The strategic objective of the institution is to ensure a high level of consumer protection in a fair competitive market that is to its benefit (Neacsu \& Madar, 2019). These opportunities can differently influence customer satisfaction and loyalty in the online environment compared to the offline environment.

The online shopping experience could also change customers' expectations about these services if they contained more information, including visual information before placing an order, and thus customers would be less susceptible to the product received than when making an order. choice from the offline environment (Venkatesh, Smith, Rangaswamy, 2003).

\section{Methodology}

In order to conduct research on "Opinions and attitudes of Romanians on the purchase of food products from online sales outlets and offline" we used quantitative marketing research based on a questionnaire consisting of 19 questions. The sampling method selected was the non-random one, the respondents being interviewed online.

Data collection was done by sending the questionnaire link online (the questionnaire was made in Google Forms) through social networking sites, in groups and individually by e-mail to selected people from a database with contact addresses. The questions refer to aspects regarding the buyers' behaviors towards the purchase of products from the online environment, as well as from the offline environment, supermarkets / hypermarkets.

The basic population of this research consists of Romanian residents, both men and women over 15 years of age, which in 2018 amounted to $16,478,152$ people according to the same (Institutul Naţional de Statistică (2019).

Table 1. Gender-based sample structure

\begin{tabular}{|l|l|l|l|l|}
\hline & Absolute frequency & Percentage & Valid percentage & $\begin{array}{l}\text { Cumulative } \\
\text { percentage }\end{array}$ \\
\hline Female & 315 & 52,5 & 52,5 & 52,5 \\
\hline Male & 285 & 47,5 & 47,5 & 100 \\
\hline Total & 600 & 100 & 100 & - \\
\hline
\end{tabular}

Source: Authors' own research. 
We specify that answers were obtained from 600 people, and after collecting the data they were statistically processed with the help of the SPSS program Statistical Package for Social Sciences (Constantin, 2006).

The research objectives took into account the following aspects:

- Identifying how consumers prefer to shop? (online or in physical stores);

- Identification of the most frequented hypermarkets / commercial sites for the purchase of foodstuffs;

- Determining the frequency with which people usually buy food from the online environment, but also from hypermarkets;

- Determining the main reasons why consumers choose a certain hypermarket / online site;

- Identifying trends in online commerce;

- Identify the reasons that prevent consumers from using online commerce more often.

\section{Results and discussions}

Data analysis led to the following results:

When asked about the way to buy food, online or offline, the respondents, in proportion of $72 \%$, stated that they buy from offline, so directly from physical stores. We notice that a very important percentage, $28 \%$ of the 600 respondents buy food products online (Figure 1).

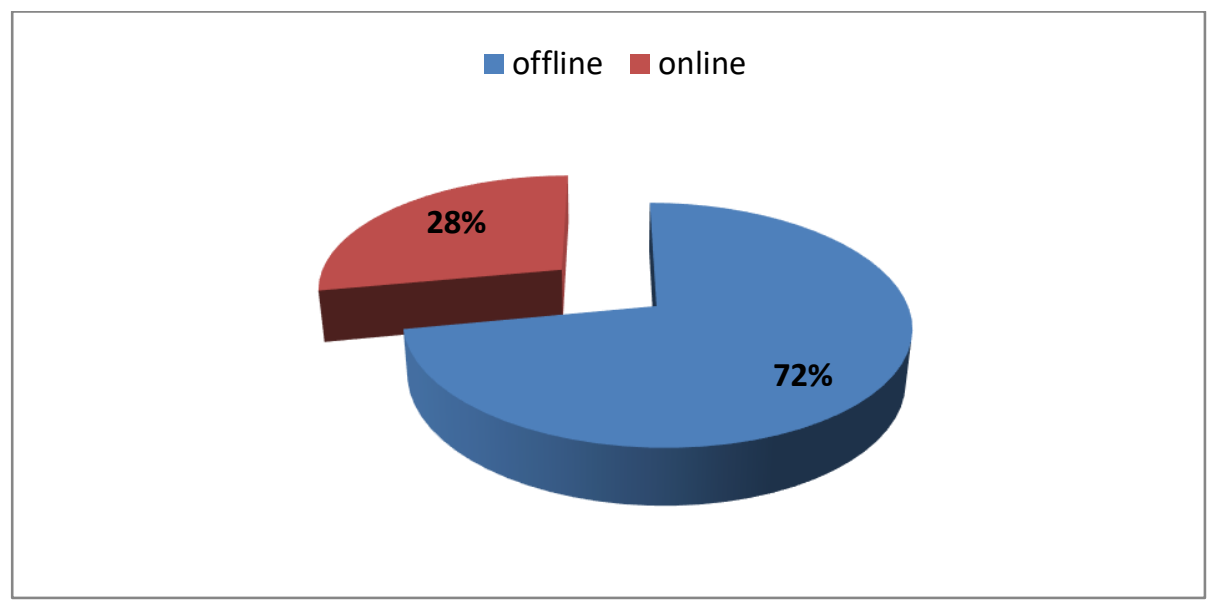

Figure 1. The way of purchasing food goods

Source: Authors' own research.

When asked if they are satisfied with the services offered by the online stores, the respondents offered the following answers: (we consider a scale from 1 to 5, where 1 represents very dissatisfied, and 5 - very satisfied). We notice that 118 people $(70.24 \%$ ) appreciate that they are very satisfied with the services offered, 10 of the respondents (5.95\%) are completely dissatisfied (Figure 2). 


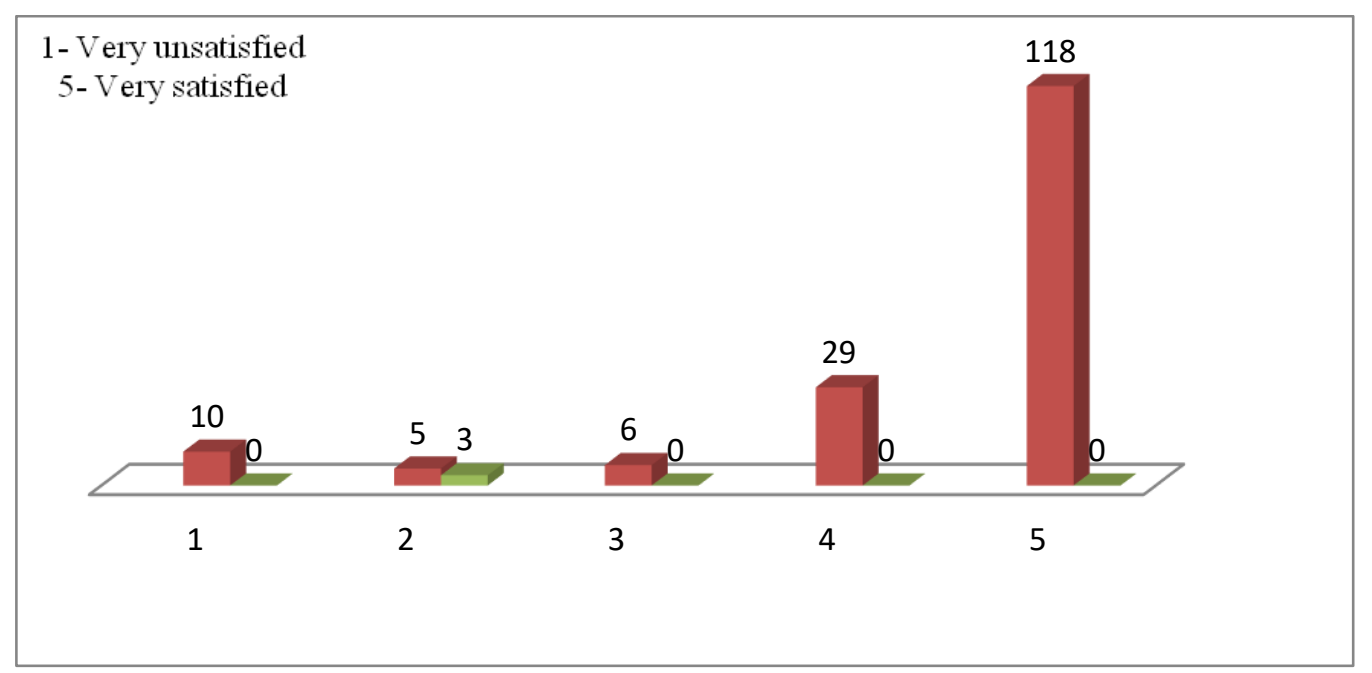

PICBE |

615

Figure 2. The measure of satisfaction with the services offered by online stores

Source: Authors' own research.

The question regarding the degree of satisfaction for the services offered by offline stores is very important, and in this case the following conclusions were drawn: 285 respondents $(47,5) \%$ stated that they are very satisfied with the services offered by classic stores (offline), 190 respondents $(31,7 \%)$ declare satisfied, and $105(17,5 \%)$ are at level 3 of satisfaction, so neither satisfied nor dissatisfied. There was no response in which the services offered by offline stores were considered very unsatisfactory (Figure 3).

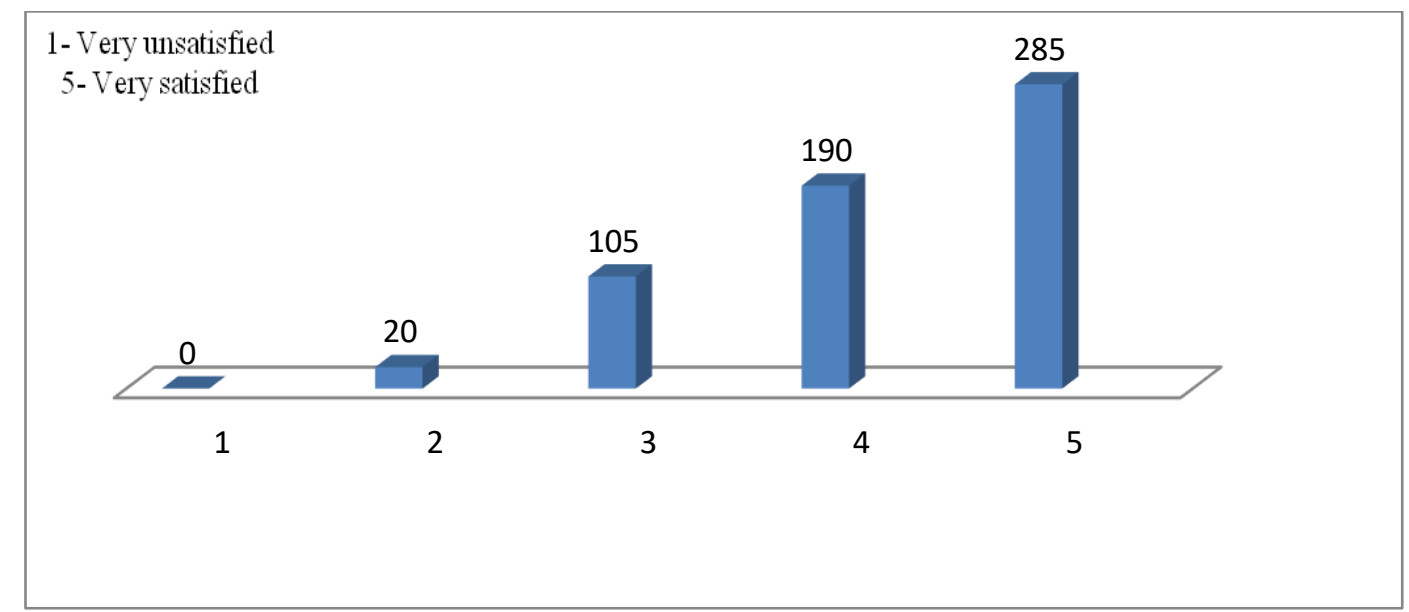

Figure 3. The measure of satisfaction with the services offered by offline stores

Source: Authors' own research.

We also find that the best known online food store from which respondents have purchased goods at least once is Carrefour with a percentage of 39.5\%, followed by Mega Image and Emag with an equal percentage of $31.6 \%$. On the 3rd place is Deliveryman with a percentage of $15.8 \%$. Shopidoki is known by $5.3 \%$ of respondents, and Kaufland by $2.6 \%$ (Table 2). 
Table 2. What online stores that sell groceries do you know?

\begin{tabular}{|l|l|l|l|l|}
\hline & Absolute frequency & Percentage & Valid percentage & Cumulative percentage \\
\hline Mega Image & 60 & 25 & 31,6 & 31,6 \\
\hline Emag & 60 & 25 & 31,6 & 63,2 \\
\hline Carrefour & 75 & 31,25 & 39,5 & 102,7 \\
\hline Shopidoki & 10 & 4,16 & 5,3 & 108 \\
\hline Deliveryman & 30 & 12,5 & 15,8 & 123,8 \\
\hline Kaufland & 5 & 2,08 & 2,6 & 126,4 \\
\hline Valid responses & 175 & 31,67 & - & - \\
\hline No response & 425 & 68,33 & - & - \\
\hline \multicolumn{1}{|c|}{ Total } & 600 & 100 & - & - \\
\hline
\end{tabular}

PICBE |

A very important question is related to the frequency with which respondents purchase food from online stores. In this case, the results are as follows: $38 \%$ of the answers are for the option-2 times / month, very close percentage is the option- once a month (27\%). Only 5\% of respondents said they buy products online, over 4 times / month. A percentage of $14 \%$ even state that they buy products less than once a month (Figure 4).

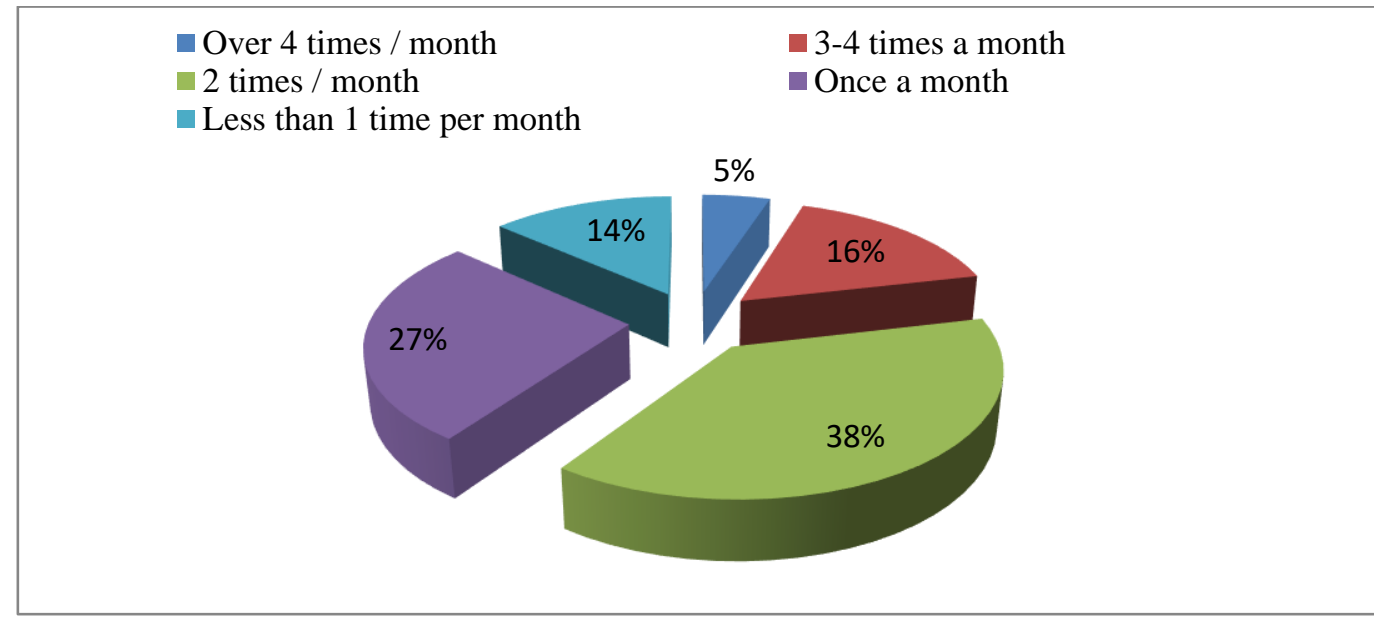

Figure 4. The frequency of buying food from online stores

Source: Authors' own research.

We considered it necessary to find out the reasons why some respondents do not buy food online. The reasons are set out in the following table:

Following the analysis, we found that the most important reason why respondents choose not to buy food online is the delay of the order $(31.95 \%)$, followed by the reason for distrust in online stores $(27.83 \%)$ and the reason related to fear of being cheated (17.52\%) (Table 3$)$. 
Table 3. Why consumers don't buy food from online stores

\begin{tabular}{|l|l|l|l|}
\hline \multicolumn{1}{|c|}{ Valid responses } & \multicolumn{1}{c|}{$\begin{array}{c}\text { Absolute } \\
\text { frequency }\end{array}$} & \multicolumn{1}{c|}{ Percentage } & Valid Percentage \\
\hline For fear of being cheated & 85 & 17,52 & 20,7 \\
\hline Order delay & 155 & 31,95 & 37,8 \\
\hline I did not have the chance & 5 & 1,03 & 1,2 \\
\hline I didn't want to & 5 & 1,03 & 1,2 \\
\hline I prefer to go to the store & 5 & 1,03 & 1,2 \\
\hline Food quality & 5 & 1,03 & 1,2 \\
\hline The high price of the transport tax & 5 & 1,03 & 1,2 \\
\hline I prefer to do my own shopping & 5 & 1,03 & 1,2 \\
\hline $\begin{array}{l}\text { I couldn't find a suitable online store for } \\
\text { me }\end{array}$ & 5 & 1,03 & 1,2 \\
\hline Lack of trust in online stores & 135 & 27,83 & 32,9 \\
\hline I prefer to choose the products myself & 5 & 1,03 & 1,2 \\
\hline The products may not be fresh & 5 & 1,03 & 1,2 \\
\hline Distrust of the delivery system & 5 & 1,03 & 1,2 \\
\hline $\begin{array}{l}\text { The need to receive food in a timely } \\
\text { manner }\end{array}$ & 5 & 1,03 & 1,2 \\
\hline Valid responses & 430 & 71,67 & - \\
\hline No responses & 170 & 28,33 & - \\
\hline \multicolumn{1}{|c|}{ Total } & 600 & 100 & - \\
\hline
\end{tabular}

Source: Authors' own research.

Consumers' preferences regarding offline stores are diverse, of which most respondents with a percentage of $21.51 \%$ have as their main reason the possibility to choose the product at the place of sale. In 2nd place is in an equal percentage of $16 \%$ speed and safety.

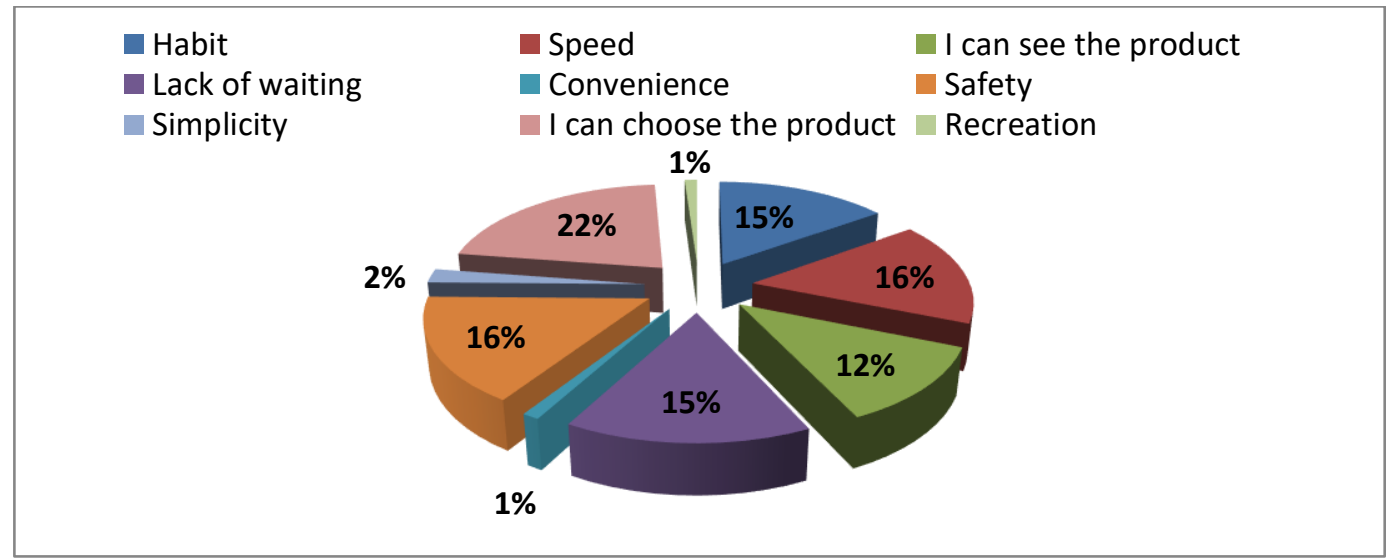

Figure 5. Consumer preferences regarding offline stores

Source: Authors' own research.

In the top 3 are also the habit and lack of expectation with an equal percentage of $15.05 \%$. The opportunity to see the products is also a reason for many consumers and has a percentage of $12 \%$. Also, $2 \%$ of respondents consider it simpler, and on the last place with a percentage equal to $1 \%$ is convenience and recreation (Figure 5). 
Analyzing the relationship between age and how people prefer to shop, it can be seen that people who prefer online commerce are between 36-45 years old, they chose online shopping in a percentage of $51.2 \%$ compared to other age groups who chose more offline shopping. The lowest percentages were registered in the case of people aged between $15-25$ years (10\% percentage) and 26-35 years (19.8 percent). So younger people have said they prefer offline commerce, probably because it's easier for them to get around and they want to walk at the same time. It is more difficult for the elderly to travel, which is why they resorted to online commerce. So in this case the connection between age and how people prefer to shop is there.

\section{Conclusion}

At present, the activity of a store, especially of large supermarket chains is impossible without the involvement of the online environment, the two environments being in close connection and not being able to function without each other.

Consumers who were previously hesitant to shop online, either because they were reluctant to adopt the technology or because they preferred to personally choose fresh produce, have now experienced this way of shopping and are unlikely to give it up in the future. At the same time, consumers are becoming more and more satisfied with online services, which they associate with trust, convenience and relaxation.

The decree of the state of emergency caused by the pandemic caused the sales in the stores to explode, especially in the food retail. We notice and affirm that the retail of food goods in the online environment is very young on the Romanian market, compared to the one in the offline environment, which is much more developed.

At the same time, large chain stores can easily gain the trust of customers because they are stores with a history, which have a strong image formed in the vision of consumers, which ensures the quality and safety of products.

For any business that wants to be known and respected by consumers, it is important to promote their business as well as possible, but also the products they sell.

Also after conducting quantitative research, I noticed that Romanians are still skeptical about buying online, especially food and prefer more the classic way in physical stores, which I found out they are very satisfied. Offline commerce seems to give them more confidence in the correctness of the purchase made and that the product is exactly the one they wanted, because they can see and check the condition of the food before buying it.

However, online and physical stores are not in competition, but in many cases complement each other and borrow their features. Large companies are trying to be strongly present both in classic retail and online.

On the other hand, online stores try to overcome the disadvantage of people not being able to touch the products, through as many suggestive pictures and detailed descriptions on their websites.

At the same time, customers who are very satisfied with online platforms, claim that they benefit from this type of trade due to the promotions that retailers do only for online platforms, the ability to purchase products with a simple click, especially for consumers who want to buy larger quantities and do not have a means of transport, but also the various ranges of products available.

The final conclusion after conducting the research is that we still have a behavior that goes to offline shopping, when it comes to foodstuffs, but in this period of the COVID-19 pandemic, there was an increase in the percentage of Romanians who went to online shopping. 
We believe that the dynamics of information and communication technologies, as well as the current pandemic situation have led and will continue to lead to profound changes in trade. It evolves more and more, from year to year, but at the same time it is modeled after the consumer's behavior trying to satisfy the needs of all potential customers.

\section{References}

Boitor, B., Boșcor, D., Brătucu, G., Tălpău, A. (2011). Impact of new online ways of advertising, Bulletin of the Transilvania University of Braşov, Series V, 4(53), no. 2, 6-7.

Chaffey, D., Ellis-Chadwick, F. (2016). DigitalMarketing - Strategy,implementation and practice, ed. Pearson, United Kingdom, 120.

Colțea, T., Gherghina, V., Gribincea, A., Roșcăneanu, R. (2013). Inovațiile în comerțul modern, Seria Stiințe exacte și economice, Universitatea de stat din Moldova, 40.

Constantin, C. (2006). Sisteme informatice de marketing, ed. Infomarket, Brasov, 30-31.

Dobre, C., Milovan, A.M. (2019). Marketing online și social media, Editura C.H. Beck, București, 33-34.

Neacsu, N.A., Armasar, P. (2018). Using digital marketing tools in higher education. A case study - Romania, 11 ${ }^{\text {th }}$ Annual International Conference of Education, Research and Innovation (ICERI), Seville, Book Series: ICERI Proceedings, 7695-7703.

Neacsu, N.A., Madar A. (2019). The influence of consumer protection on the satisfaction of airline passenger, $13^{\text {th }}$ International Conference on Business Excellence (ICBE) Sustainable Business Models and Innovation in the Knowledge Economy, 1(1), Bucharest, 112-124.

Noor, F.I, Wang, X. (2019). Decoding the sentiment dynamics of online retailing customers: Time series analysis of social media, Computers in Human Behavior - Volume 96, July 2019, 32-45.

Venkatesh, S., Smith, A.K, Rangaswamy, A. (2003). Customer satisfaction and loyalty in online and offline environments, International Journal of Research in Marketing, 20(2), 153-175.

Wenthru, R. (2016). The online - offline balance: internationalization for Swedish online service providers, Int Entrep, Journal of International entrepreneurship, 14(4), 575-577, https://www.econbiz.de/Record/the-online-offline-balance-internationalization-forswedish-online-service-providers-wentrup-robert/10011719248.

Institutul Naţional de Statistică (2019). Romania în cifre, available online at: https://insse.ro/cms/sites/default/files/field/publicatii/romania_in_cifre_2019_2.pdf, accesses on: 14.02.2020. 